\title{
"Will the Resources Head Wag the Imperative Tail?"
}

The Carnegie Commission on Higher Education has just published another report entitled The More Effective Use of Resources: An Imperative for Higher Education. The study has serious implications for libraries because its recommendations directly affect patterns and level of use, and the service capabilities of libraries. The thrust of the report is that ". . . about $\$ 10$ billion (in 1970-71 dollars) can be taken away from the prospective expenditures that would be made on higher education in 1980-81 if the trends of the 1960s were to be followed."

That's right, we are talking about reductions in funding. While the report repeatedly states that budgets for new books and periodicals should not be cut, it is clear that other major portions of library expenditures are not so favored. The Commission supports its $\$ 10$ billion figure with such an alarmingly detailed array of data and with such closely-reasoned projections that one is led to the ineluctable conclusion that, willy-nilly, the soaring sixties are going to be followed by the stringent seventies, which will be followed by the stagnant eighties. In short, the Commission has carefully analyzed costs and growth in American higher education and has concluded that they are too high and we have had enough.

What does this mean for you and me? Assuming that some, even if not all, of the Commission's recommendations are translated into reality, we can look forward to the following:

(1) A drastic halt in the creation of new $\mathrm{Ph} . \mathrm{D}$. programs, and a reduction in the number of $\mathrm{Ph} . \mathrm{D}$. programs already in existence. In the humanities and social sciences-the heaviest users of library materials at the $\mathrm{Ph} . \mathrm{D}$. level-we will have to change our acquisitions policies and even many procedures. Large-scale buying in new fields will almost certainly not occur as it has in the past. Habits of mind acquired in the sixties will have to be altered to conform to the new conditions of scholarly expansion.

(2) A reduction in the number of students may be imminent. In 1960 we had some three million students enrolled; in 1970 we had doubled that figure. But in 1980 we can look forward to less than ten million full-time students. And beyond 1980, the mathematics of a zero-population growth point inexorably to a decline in the number of college-age students. Further, the Commission recommends the three-year B.A. degree, credit by examinations, the year-round school, and a variety of other methods for achieving more intensive use of existing resources. Before any of these recommendations are realized in our own school, we had better sit down with our presidents and deans and translate each into library costs saved and incurred. If course credit by examination is to become widespread, it is obvious that patterns of library use will change-and probably for the better. And with the decline in the 18-22 year-old college student, there might be an increase in the number of older students enrolled. Every reference librarian knows there is a difference between the student and the "mature" student. But do their administrators?

(3) A leveling off of salaries. In the 1960s, faculty salaries not only rose with the general cost of living, but increased by an additional three percent annually. 
In the 1970s, the Commission estimates, faculty salaries will better the cost of living rate only by one or two percent, whereas wages generally will rise above the cost of living rate by two to three percent. The tug of war between academics and the rest of the country's wage earners will not be in favor of the academics for quite some time. Are you ready for that? And if a deteriorating job market combines with financial stringency to produce unfavorable employment conditions, we can be fairly certain that large-scale unionization will result. Indeed the trend in this direction as of 1972 is obvious. Have you and your friendly local administrator gotten together to work out successful collective bargaining relationships? After all those battles over academic status, is it time now-is there time now-to think about hitching the library wagon to a different star? There is the good old red dwarf of the AAUP and the supernova of the AFT; dare we look at the quasar in the other corner or the suspected but nearly unimaginable quark in still another direction?

(4) An increase in the number and variety of consortia between academic institutions. For the library, such cooperative efforts will certainly have to result in something more than verbiage, more even than jazzed-up interlibrary loaning. Why do we have to wait for the situation to overtake us before we effectively knuckle down to sharing resources and (probably more important) eliminating duplication of processing effort? As college administrators better perceive the realities of the budget, they are going to chip away further at the library's infrastructure-better known in many places as the Technical Services Division. And really now: why should anyone be asked to accept as necessary a five to ten dollar unit cost for processing a book? It is not only outrageously high, it is outrageously silly; and although you and I have learned to live with (even accept) exorbitant processing costs, it does not follow that our presidents havenot to mention other assorted taxpayers such as truck drivers, faculty members, bartenders, or legislators.

The conclusion seems inescapable: we must grope with, if not cope with, changes in our acquisitions policies, in our student population, in our conditions of employment, and in our relations with libraries in sister institutions. The world of learning is not going to contract, to be sure, but we are going to have to learn better how to gear our acquisitions more precisely to the teaching and research needs on campus. We are going to have to satisfy students who are older, who are no longer academic virgins, who may have more questing minds-and not just about academic subjects, but about academic management. We may find ourselves making more but enjoying it less, and who can say that our thinking about our labor relations will continue to bifurcate into simplistic professionalism vs. unionism? Is it not possible, finally, to think of interlibrary cooperation in more than cataclysmic/bogus terms? We may find that we have stretched the budgets for books too thinly in relation to the budgets for processing them.

As the proverbial wag put it, the dinosaur disappeared because his head got too far away from his tail.

W. H. WEBB 